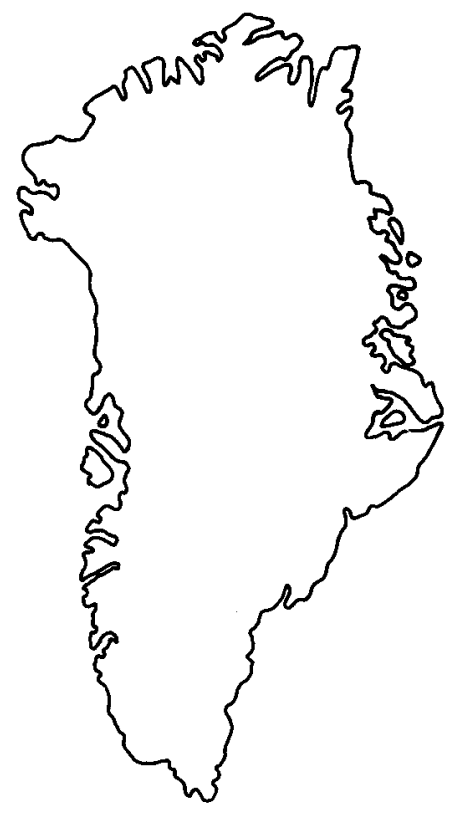

\title{
Volcanic marker horizons in the Maligât Formation on Disko and Nûgssuaq, and implications for the development of the southern part of the West Greenland basin in the early Tertiary
}

\author{
Lotte Melchior Larsen and Asger Ken Pedersen
}

\begin{abstract}
Two volcanic units in the feldspar-phyric basalts of the Rinks Dal Member each have a distinct chemical composition and sometimes lithology, and can be recognised over large areas. A pahoehoe unit filled a $c .60 \mathrm{~m}$ deep water basin which existed over a long period in eastern Disko, confined between the Disko gneiss ridge in the west, volcanics in the north, and a fluvial plain in the south-east. After the deposition of the pahoehoe unit the topography was considerably more even, and a FeTi unit was able to spread throughout Disko and southern Nûgssuaq. The FeTi unit consists of subaerial lavas and is thickest in the west where the eruption sites were located; it thins gradually toward the east, and in the eastern parts it is intercalated with sandstones and shales. The FeTi lavas have sometimes invaded the sediments to form sill-like bodies. Intercalated with the FeTi unit are shales of the Aussivik Member on Nûgssuaq, shales and sandstones on northern east Disko, and sandstones throughout the rest of Disko. Thus lateral time-equivalent facies differences are demonstrated. The general palaeoslope from west to east shows that the continental margin to the west had not yet begun to sag.
\end{abstract}

L. M. L., Geological Survey of Greenland, Øster Voldgade 10, DK-1350 Copenhagen $K$, Denmark.

A. K. P., Geological Museum, Øster Voldgade 5-7, DK-1350 Copenhagen K, Denmark.

\section{Introduction}

The mapping and geochemical analysis programme for the early Tertiary lavas on Disko and Nûgssuaq, which form the southern part of the West Greenland basin, is now so far advanced that regional pictures for a number of units in the volcanic series are emerging. Some of these units are the products of comparatively short-lived volcanic events and can therefore be used as time-markers. In this report we describe two such timemarkers in the Rinks Dal Member of the early Tertiary Maligât Formation and discuss their implications for the analysis of the development of the southern part of the West Greenland basin.

The volcanic rocks on Disko and Nûgssuaq (see fig. 4 for place names) are divided into a lower formation dominated by picrites (the Vaigat Formation) and an upper formation of feldspar-phyric differentiated basalts (the Maligât Formation) (Hald \& Pedersen, 1975).
These formations have been subdivided into members by Pedersen (1975a, 1985) and Hald (1976). Some of these members can be followed over almost the whole region, while others are of more local extent.

On Disko island the Maligât Formation comprises three members: Rinks Dal, Nordfjord and Niaqussat Members, mentioned from bottom to top.

\section{Rinks Dal Member}

The Rinks Dal Member is up to $c .1400 \mathrm{~m}$ thick and consists mainly of thick (10-100 m), massive, trap-forming lava flows of rather uniform appearance. The member is present throughout the basalt areas of Disko and eastern Nûgssuaq. In south-central Nûgssuaq and northern Disko the member rests on the Vaigat Formation, while to the south and east it rests on and interfingers with contemporary sandstones and shales and engulfs the Disko gneiss ridge in southern and central 
Disko. The Rinks Dal Member is overlain by sedimentcontaminated lavas of the Nordfjord Member.

A number of flow-by-flow sampled profiles have been made through the Rinks Dal Member. Geochemical analyses show that some horizons with a distinctive chemical composition can be identified in many profiles (fig. 1). Four distinct geochemical groups are recognised by their $\mathrm{TiO}_{2}-\mathrm{MgO}$ ratios (fig. 2). Representative compositions of lavas from these groups are given in Table 1. Where the member is fully developed, the characteristic feature is the occurrence of a number of very $\mathrm{TiO}_{2}^{-}$ rich lavas in the middle of the member. A prominent unit of pahoehoe lavas and associated breccias in eastern Disko occurs a little below the $\mathrm{TiO}_{2}$-rich unit. These two units are described in some detail below, under the informal names of the pahoehoe unit and the FeTi unit.

\section{Pahoehoe unit}

The pahoehoe unit is present over large areas in eastern Disko and must also be present beneath a large part of the central ice cap (Sermerssuaq). The western margin of the unit is not delimited, but it is not known from the gneiss ridge and west of this (fig. 4). In eastern Disko the pahoehoe unit forms a c. $60 \mathrm{~m}$ thick crossbedded sequence of pillow breccias with overlying subaerial thin pahoehoe lavas (fig. 3). This unit occurs in the lower part of the Rinks Dal Member, one to a few flows below the FeTi unit, and over large areas in eastern Disko it constitutes the oldest exposed volcanic rocks of the Maligât Formation.

The rocks of the pahoehoe unit have a chemical composition which is distinct from the other rocks of the

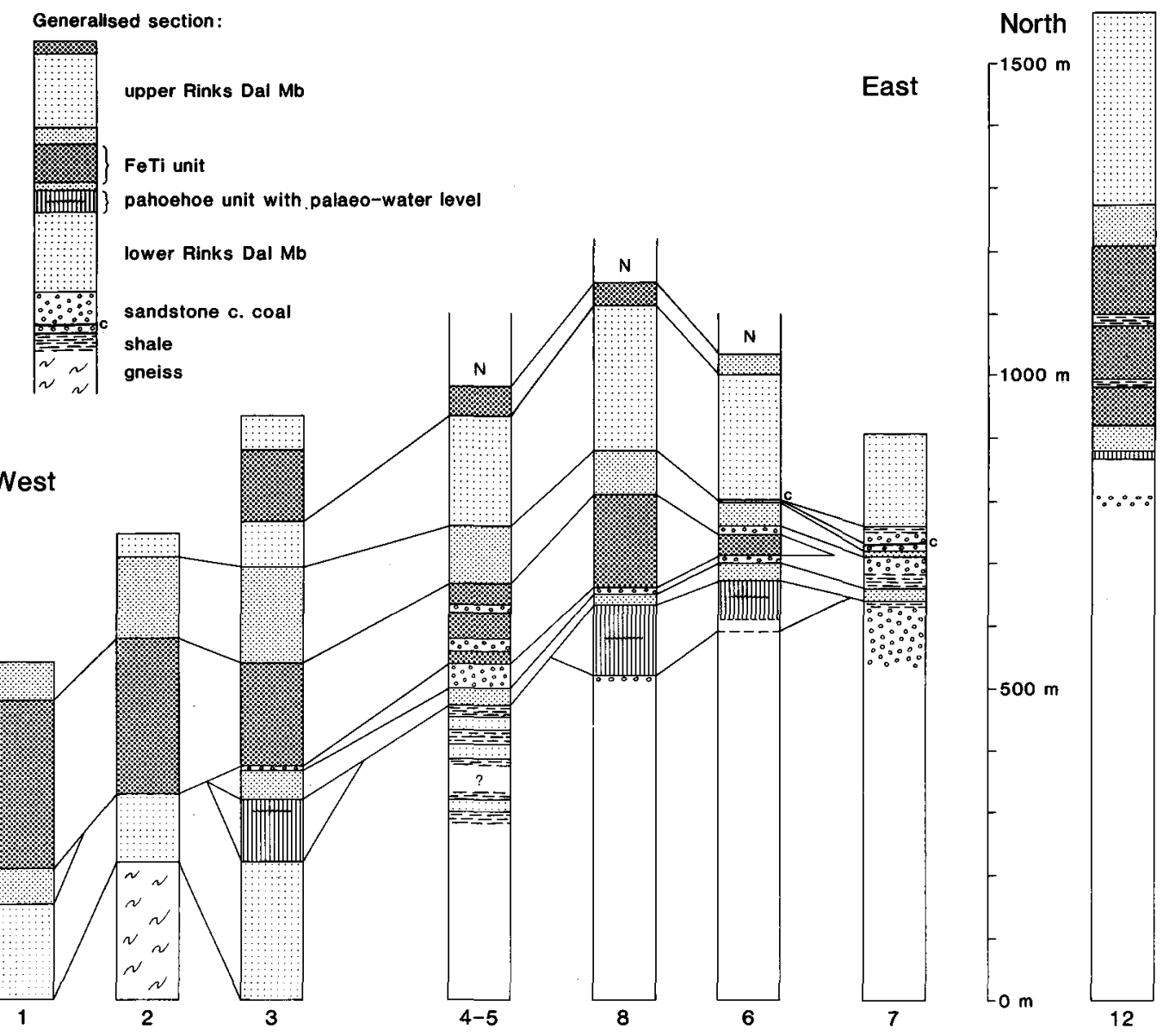

Fig. 1. Profiles through the Rinks Dal Member arranged in a west-east-north section. The occurrence of lavas from the four geochemical groups in fig. 2 is shown with the same symbols as in fig. 2. The generalised section indicates the position of the marker horizons (pahoehoe unit and FeTi unit) described in the text. $\mathbf{N}=$ Nordfjord Member. The location of the numbered profiles appears on fig. 4. 


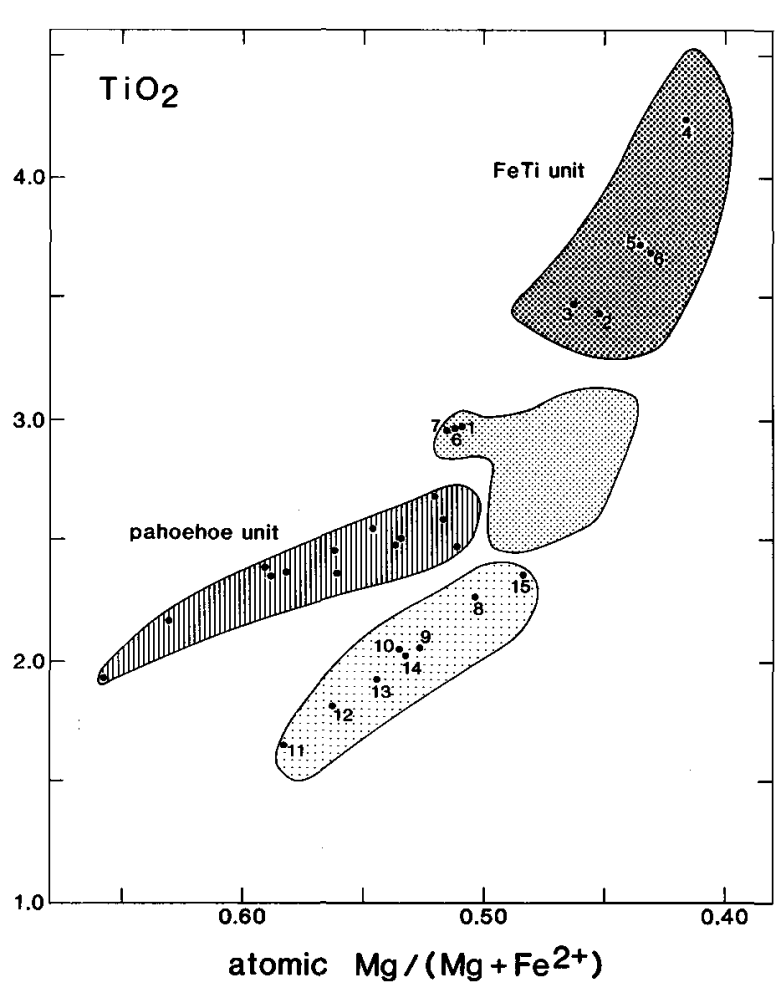

Fig. 2. Generalised $\mathrm{TiO}_{2}-\mathrm{Mg}$ ratio diagram for the lavas of the Rinks Dal Member, showing the four distinct geochemical groups. The stratigraphy of the groups appears from fig. 1, with the same symbols. As an example, data from one profile in Frederik Lange Dal (fig. 1, no 8) are shown as dots, with numbers indicating flow number in ascending order, starting above the pahoehoe lavas and breccias which are unnumbered. The bottom of this profile is shown in fig. 3 .

Rinks Dal Member (fig. 2, Table 1), and the unit sometimes includes olivine-rich nearly picritic rocks.

The pillow breccias formed when the thin pahoehoe lavas entered a large water-filled basin. The breccia horizon is an excellent field marker, which can not only be recognised from distances of many kilometres, but can also be identified when found in small disrupted exposures in the numerous landslides. Therefore, the extent of the water-filled basin at the time of eruption of the unit can be delimited. The presently known extent of the pahoehoe unit is shown in fig. 4.

In southern Disko the unit has been investigated in detail by Heinesen (1987) as part of a study of subaqueous volcanic units from the Rinks Dal Member in Skarvefjeld. Here, large subaqueous lava flows and hyaloclastites of older units from the Rinks Dal Member have partly filled the basin east of the Disko gneiss ridge. The pahoehoe unit has filled parts of the basin along a $\mathrm{N}-\mathrm{S}$ elongated belt about $10 \mathrm{~km}$ wide, and the orientation of the cross-bedding in the pillow breccias clearly shows that they formed from lavas which flowed into the basin from the north (Heinesen, 1987).

In eastern Disko the pahoehoe unit rests on badly exposed shales or silty sandstones, in which a hardened horizon at the top has been noted. The presence or absence of the breccias of this unit, as shown in fig. 4, probably delimits the water-filled basin approximately, but it is also possible that the basin extended further to the east and just did not receive enough volcanic material to fill it out laterally. The water depth was $60-70 \mathrm{~m}$, and the breccias are overlain by $10-50 \mathrm{~m}$ of subaerial pahoehoe flows (figs 3 and 7). Due to poor exposures it is very difficult to point out the time-equivalent level in the sediments in those parts of eastern Disko where the pahoehoe unit is not present. However, in eastern Disko the pahoehoe unit is followed by an extensive and chemically distinct lava flow which can be recognised in the sediments also in places where the pahoehoe unit is not present, and upon this follows the FeTi unit (fig. 7). This places an upper limit on the possible equivalent sediments.

The extent of the water-filled basin can be delimited toward the north-west as shown in fig. 4. Between Inugsuk and Qutdligssat the breccias disappear, but a characteristic series of thin grey subaerial pahoehoe lavas continues towards the north-west.

At Giesecke Monument on Nûgssuaq a single, poorly exposed basalt with the distinctive chemical composition of the pahoehoe unit is found within poorly exposed Tertiary sediments at the base of the Rinks Dal Member. This probably indicates that the pahoehoe unit extends to southern Nûgssuaq.

The eruption sites for the pahoehoe unit are inferred to be in central Disko within the confines of the waterfilled basin. The thickest lava flows and the largest variation in chemical composition, including the occurrence of the most magnesian rock types, are found in Frederik Lange Dal. The main eruption sites are therefore estimated to have been in this area, probably under Sermerssuaq. No dykes with similar chemical compositions are known.

\section{FeTi unit}

The FeTi unit consists of lava flows which all have more than $3.2 \% \mathrm{TiO}_{2}$ (fig. 2). These lavas tend to have a stronger brown colour than the surrounding lavas, but in many areas the unit is not a good field marker. On the map sheet 1:100 000 Mellemfjord (Pedersen \& UlffMøller, 1987) the unit has been mapped over large areas of western Disko by F. Ulff-Møller. The chemical analyses show that the unit is present in all investigated profiles (except one) which cover the relevant stratigra- 
Table 1. Representative compositions of lavas from the Rinks Dal Member in eastern Disko

\begin{tabular}{lrrrrrr}
\hline & 340883 & 340848 & 340857 & 340851 & 362168 & \multicolumn{1}{c}{340836} \\
\hline $\mathrm{SiO}_{2}$ & 47.33 & 47.82 & 48.88 & 47.46 & 48.75 & 48.53 \\
$\mathrm{TiO}_{2}$ & 2.18 & 2.29 & 2.93 & 4.17 & 2.94 & 1.91 \\
$\mathrm{Al}_{2} \mathrm{O}_{3}$ & 13.61 & 13.24 & 13.44 & 12.34 & 12.97 & 15.12 \\
$\mathrm{Fe}_{2} \mathrm{O}_{3}$ & 3.68 & 4.32 & 5.46 & 4.50 & 3.79 & 6.43 \\
$\mathrm{FeO}$ & 8.35 & 8.31 & 7.65 & 11.07 & 10.84 & 5.39 \\
$\mathrm{MnO}$ & 0.18 & 0.19 & 0.23 & 0.25 & 0.22 & 0.19 \\
$\mathrm{MgO}$ & 8.82 & 8.45 & 6.45 & 5.31 & 5.88 & 6.59 \\
$\mathrm{CaO}$ & 10.86 & 10.17 & 10.43 & 9.95 & 10.52 & 11.48 \\
$\mathrm{Na} 2$ & 2.14 & 2.02 & 2.52 & 2.66 & 2.70 & 2.41 \\
$\mathrm{~K}_{2} \mathrm{O}$ & 0.15 & 0.09 & 0.37 & 0.41 & 0.29 & 0.17 \\
$\mathrm{P}_{2} \mathrm{O}_{5}$ & 0.19 & 0.21 & 0.29 & 0.53 & 0.35 & 0.17 \\
volat. & 2.77 & 3.35 & 0.65 & 1.28 & 0.74 & 1.53 \\
& 100.25 & 100.45 & 99.31 & 99.93 & 99.98 & 99.90 \\
$\mathrm{Mg}$ ratio & 0.605 & 0.583 & 0.510 & 0.416 & 0.455 & 0.544 \\
\hline
\end{tabular}

340883 Pillow from pillow breccia, pahoehoe unit. Kvandal, alt. $580 \mathrm{~m}$.

340848 Subaerial pahoehoe lava, pahoehoe unit. Frederik Lange Dal profile, alt. 565 $\mathrm{m}$. This sample has lost alkalies.

340857 Lava no. 1 over pahoehoe unit. Frederik Lange Dal profile, alt. $632 \mathrm{~m}$.

340851 Lava from FeTi unit, no. 4 over pahoehoe unit. Frederik Lange Dal profile, alt. $745 \mathrm{~m}$.

362168 First lava over FeTi unit. Peak 1123 m, eastern Disko.

340836 Lava from upper part of Rinks Dal Mb, no. 13 over pahoehoe unit. Frederik Lange Dal profile, alt. $1025 \mathrm{~m}$.

The samples from the Frederik Lange Dal profile are plotted in fig. 2, and the profile is shown schematically in fig. 1 (no. 8).

$\mathrm{Mg}$ ratio: Atomic $\mathrm{Mg} /\left(\mathrm{Mg}+\mathrm{Fe}^{2+}\right)$, with the iron oxidation ratio adjusted to $\mathrm{Fe}_{2} \mathrm{O}_{3} / \mathrm{FeO}=$ 0.15 .

phic level in the Rinks Dal Member. The FeTi lavas spread out over a relatively even surface (as discussed later), and this has contributed to their extensive distribution in both Disko and Nûgssuaq (fig. 5). The eruption sites for the FeTi unit are probably centred in western Disko where the unit is thickest. F. Ulff-Møller (personal communication, 1989) has observed a feeder vent to a FeTi lava in western Disko.

In western Disko the FeTi unit is $200-400 \mathrm{~m}$ thick and occurs in the middle part of the Rinks Dal Member, as a sequence of subaerial lavas with oxidised and lateritised flow tops.

The relations in central Disko are imperfectly known, partly because of the ice cover. However, in both southern and northern Disko the FeTi unit is $150-250 \mathrm{~m}$ thick and consists of 5-10 subaerial lava flows in the middle part of the Rinks Dal Member (figs 1 and 6). The lavas have oxidised and lateritised flow tops, and lateritic soil layers locally up to $0.5 \mathrm{~m}$ thick may occur between the flows.
Going eastward, to south-eastern and eastern Disko and eastern Nûgssuaq, the number of flows in the FeTi unit gradually decreases. Concomitantly, the unit gradually loses its character of a simple subaerial basalt pile because the lavas have flowed into and become covered with non-volcanic fluvial sand and mud (fig. 5), sometimes with coal horizons. In easternmost Disko the FeTi unit has dwindled to a single $15-20 \mathrm{~m}$ thick flow with yellow sandstone above and below (fig. 7); this flow is sometimes a subaerial lava and sometimes a pillowed sill (an invasive lava, see below). At point $845 \mathrm{~m}$ in easternmost Disko the FeTi unit is missing (figs 1 and 5). The equivalent sediments are sandstones and shales. The sediments may have formed local topographic highs and lows which have prevented the lavas from entering some areas while giving rise to local ponding of lavas in other areas.

Along the south coast of Nûgssuaq 1-4 lavas from the FeTi unit and one or two lavas below it are the lowest Rinks Dal Member lavas present. They rest on picritic 
Fig. 3. The pahoehoe unit in Frederik Lange Dal; bottom of profile 8 in fig. 1. Height of cliff approx. $140 \mathrm{~m}$. Pillow breccias $(\pi)$ with mega-scale cross bedding are formed in subaqueous environment. Above a shore-line facies (sh) follow subaerial thin pahoehoe lavas $(\mathrm{Pa})$. Individual lavas can often be followed laterally from subaerial facies through the palaeo-waterlevel and into subaqueous breccia facies (from right to left in the figure). Lava no 2 above the pahoehoe unit rests on sandstone (ss) and belongs to the $\mathrm{FeTi}$ unit.

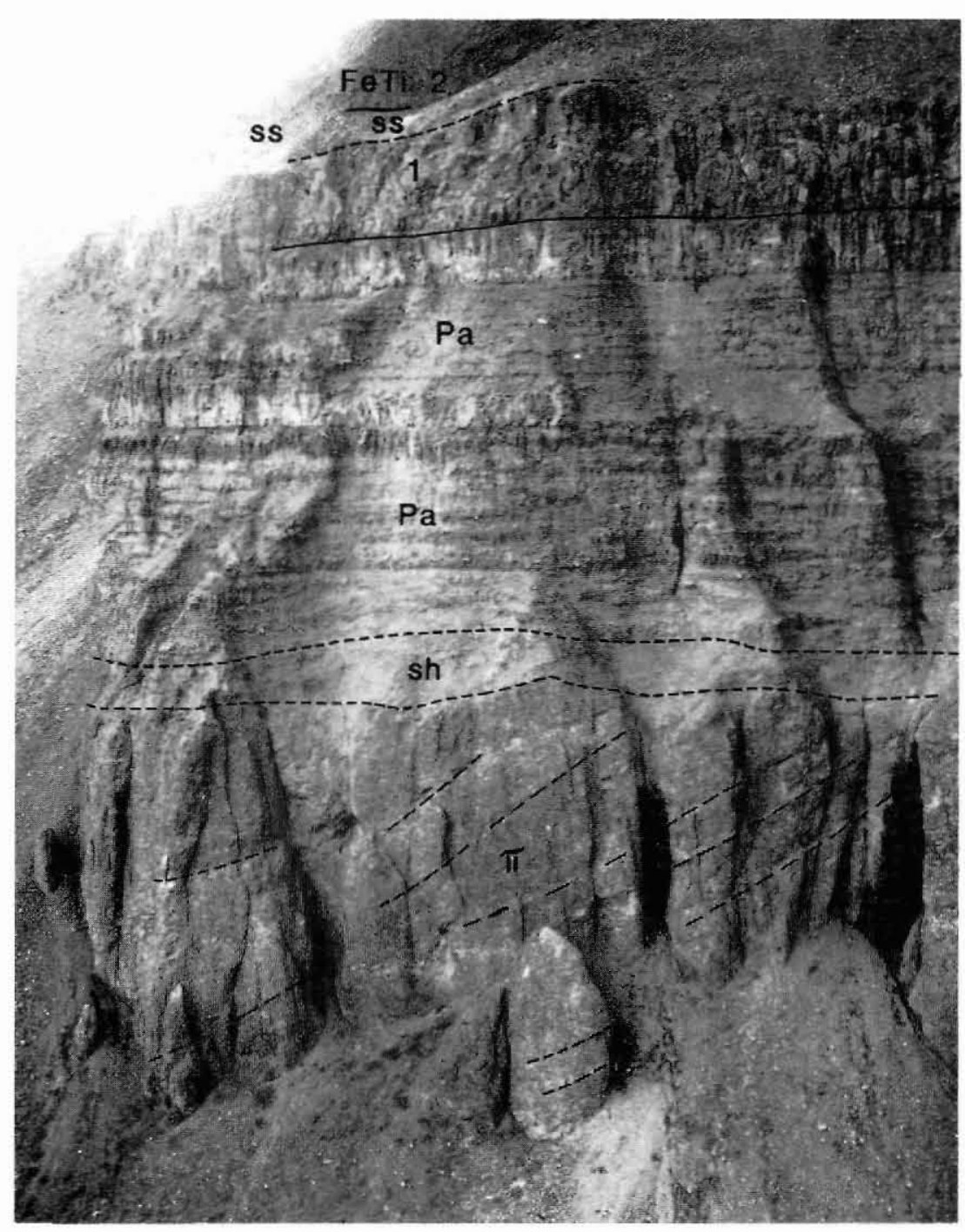

lavas from the Vaigat Formation in the west; and just south of Giesecke Monument the basal part of the FeTi unit forms two invasive lavas within siltstones and mudstones from the Aussivik Member of the Upper Atanikerdluk Formation (Koch, 1959). Due to local ponding one of these flows is more than $80 \mathrm{~m}$ thick. The upper flows of the FeTi unit at this locality are subaerial. The unit continues eastwards as one or two invasive lavas in the Aussivik Member sediments. The northern extent of the FeTi unit on Nûgssuaq is at present unknown.

\section{Invasive lavas}

The interaction between inflowing basalt lavas and wet unconsolidated sediments has produced a number of characteristic features. The most important of these is the development of invasive lavas: due to the much higher density of the basalt a lava may burrow into the sediment and continue as a sill-like body within the sediment. The 'sill' is chilled at both top and bottom, and its top may be pillowed and send offshots up into the sediment which is baked at the contact. The distinctive chemical composition of the few FeTi basalts, their stratigraphic continuity, and the complete lack of possible feeder dykes or necks within the area of lavasediment interaction, make the lava to 'sill' correlation very certain. Invasive lavas have earlier been described from the Columbia River basalts (Schmincke, 1967; Byerly \& Swanson, 1978) and from California (Duffield et al., 1986).

The presence of water in the sediments, particularly important in unconsolidated mudstones, can lead both to quenching of magma and to phreatic activity. An area with pseudocraters has been found at Marrait qá- 

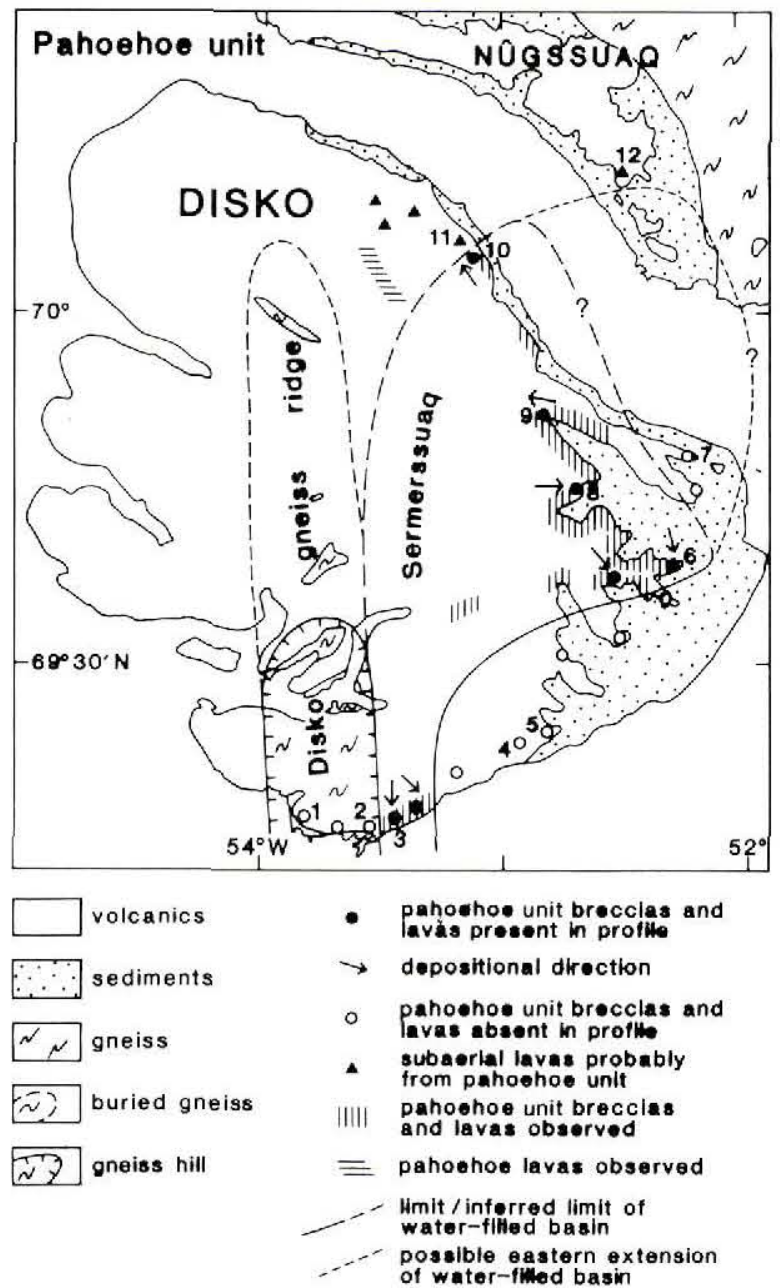

Fig. 4. Distribution of the breccias and lavas of the pahoehoe unit of the Rinks Dal Member. The extent of the water-filled basin and the Disko gneiss ridge are indicated. The map shows the main units of the present geology. Symbols mark the position of measured and sampled profiles, as follows:

1: Fortunebay, 2: Lyngmarksfjeld, 3: Skarvefjeld, 4: Marrait qáqât, 5: Tuapait qáqât, 6: peak $1123 \mathrm{~m}, 7$ : peak $845 \mathrm{~m}, 8$ : Frederik Lange Dal, 9: Kvandal bottom, 10: Inugsuk, i1: Qutdligssat, 12: Giesecke Monument.

qât in south-east Disko. An invasive FeTi basalt 'sill' is here covered by less than $5 \mathrm{~m}$ of poorly exposed sandstone on top of which lies a field of pseudocraters of basalt scoriae with a chemical composition identical to that of the underlying 'sill'. The pseudocraters are covered by a more than $30 \mathrm{~m}$ thick subaerial basalt lava also belonging to the FeTi unit but with a chemical composition distinct from the underlying 'sill' and scoriae. Just 7 $\mathrm{km}$ further to the east the flow giving rise to the 'sill' and the pseudocraters is an ordinary-looking sill buried beneath more than $10 \mathrm{~m}$ of sandstone on top of which
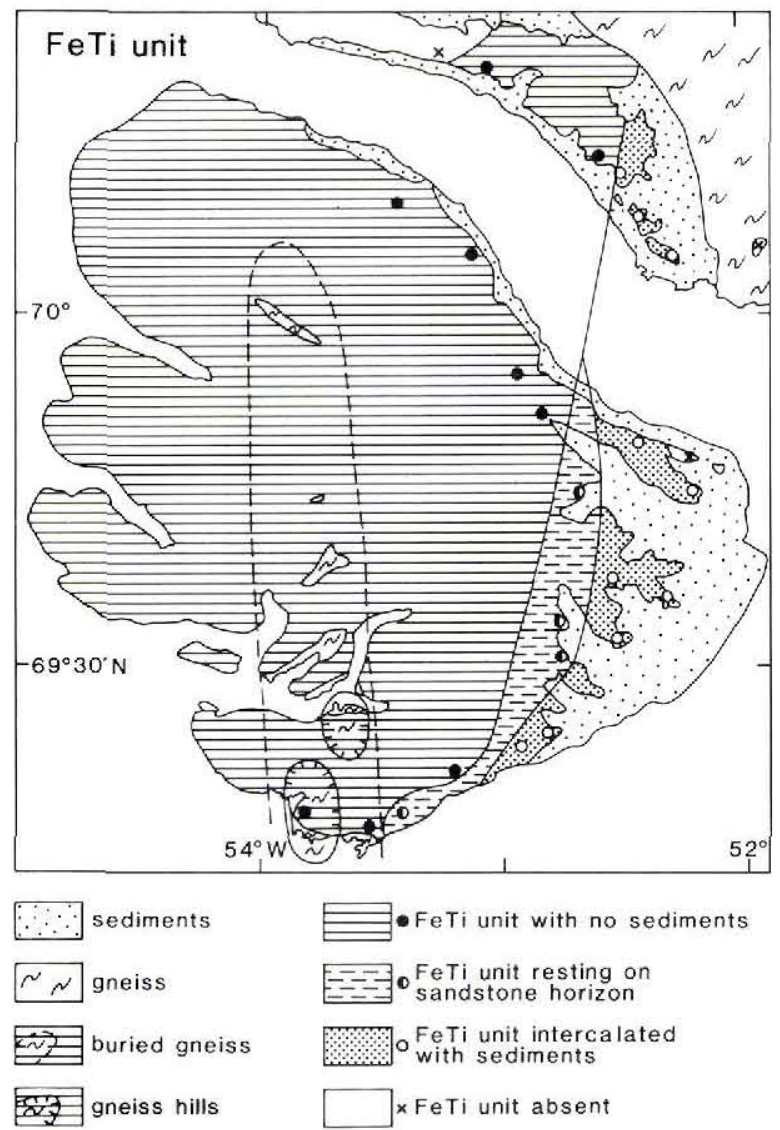

Fig. 5. Distribution of lavas of the FeTi unit of the Rinks Dal Member. At the start of the formation of this unit the Disko gneiss ridge was covered except for two small remnants in the south. In the east the sediments intercalated with the FeTi lavas are sandstones to the south and shales to the north. The map shows the main units of the present geology. Symbols mark the position of measured and sampled profiles; they are not shown in western Disko. Names appear from fig. 4 .

follows the same subaerial FeTi lava flow as at the previous locality, here with a basalt conglomerate on the top.

In south-eastern Nûgssuaq Koch (1959) and Koch \& Pedersen (1960) recognised conformable basalt layers within the shales of the Aussivik Member over long distances from Giesecke Monument and south-eastwards. They concluded that these basalts were most likely to be lavas although they were puzzled by features like baked top sediments. Pedersen (1975b) demonstrated that they were locally pillowed sills intruded in a wet environment. The present study has conclusively shown that the basalts in the Aussivik Member are invasive lavas, and that Koch (1959) and Koch \& Pedersen (1960) came remarkably close to the truth in 
Fig. 6. Rinks Dal Member in southern Disko at Lyngmarksfjeld (profile 2 in figs 1 and 4 ). The member rests on the Disko gneiss ridge, and the FeTi unit consists of 7-8 subaerial lava flows with thick light (red) top zones.

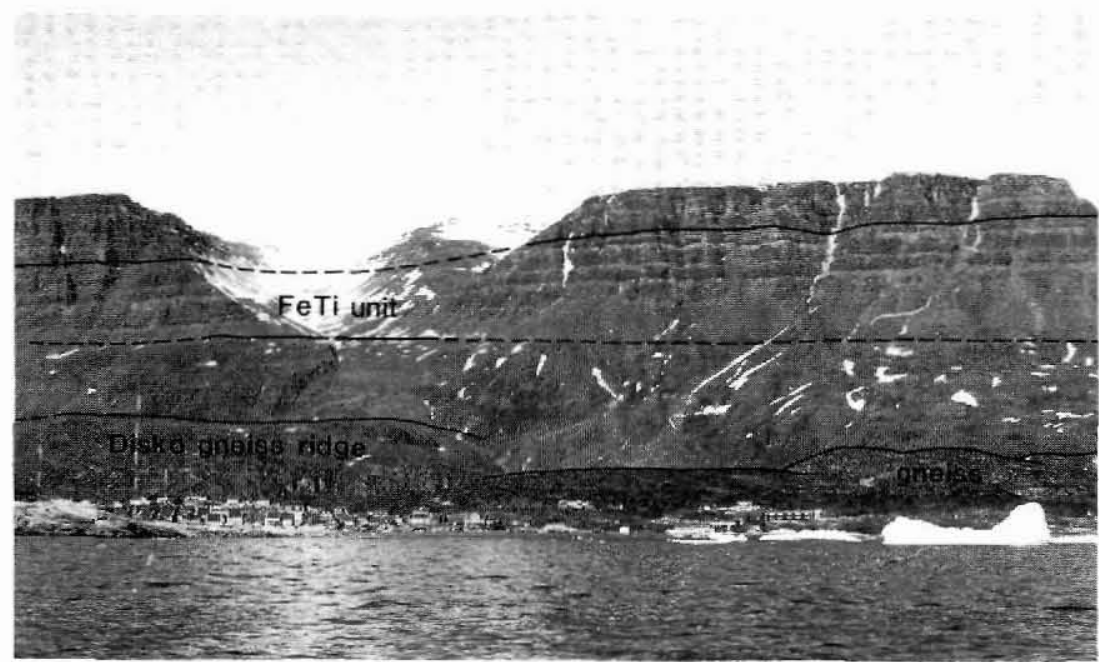

their reflections on these basalts. The upper of these 'sills' belongs to the FeTi unit.

\section{Basin development}

Because of their distinctive chemical composition, widespread distribution and varying facies development the pahoehoe unit and the FeTi unit in the Rinks Dal Member are valuable stratigraphic tools in the analysis of basin development along the south-eastern margin of the West Greenland basin. These units interfinger over large areas with non-volcanic clastic sediments and are thereby useful for setting stratigraphic constraints on the sequences of mainly non-marine Tertiary sediments which are poorly exposed over large parts of the region. They also give indications of uplift and sagging events which are important factors in the evolution of the continental margin.

The identification of the FeTi unit on both Disko and Nûgssuaq has clearly demonstrated that the boundary between the Vaigat and Maligât Formations is complex. While the FeTi unit on Disko occurs in the middle of the Rinks Dal Member, the unit laps directly onto the picrites of the Vaigat Formation on south-central Nûgs-
Fig. 7. Rinks Dal Member in eastern Disko at peak $1123 \mathrm{~m}$ (profile 6 in figs 1 and 4). Pillow breccias $(\pi)$ and pahoehoe lavas (Pa) of the pahoehoe unit at the bottom of the sequence. The FeTi unit consists of one lava flow with sandstone (ss) at both base and top.

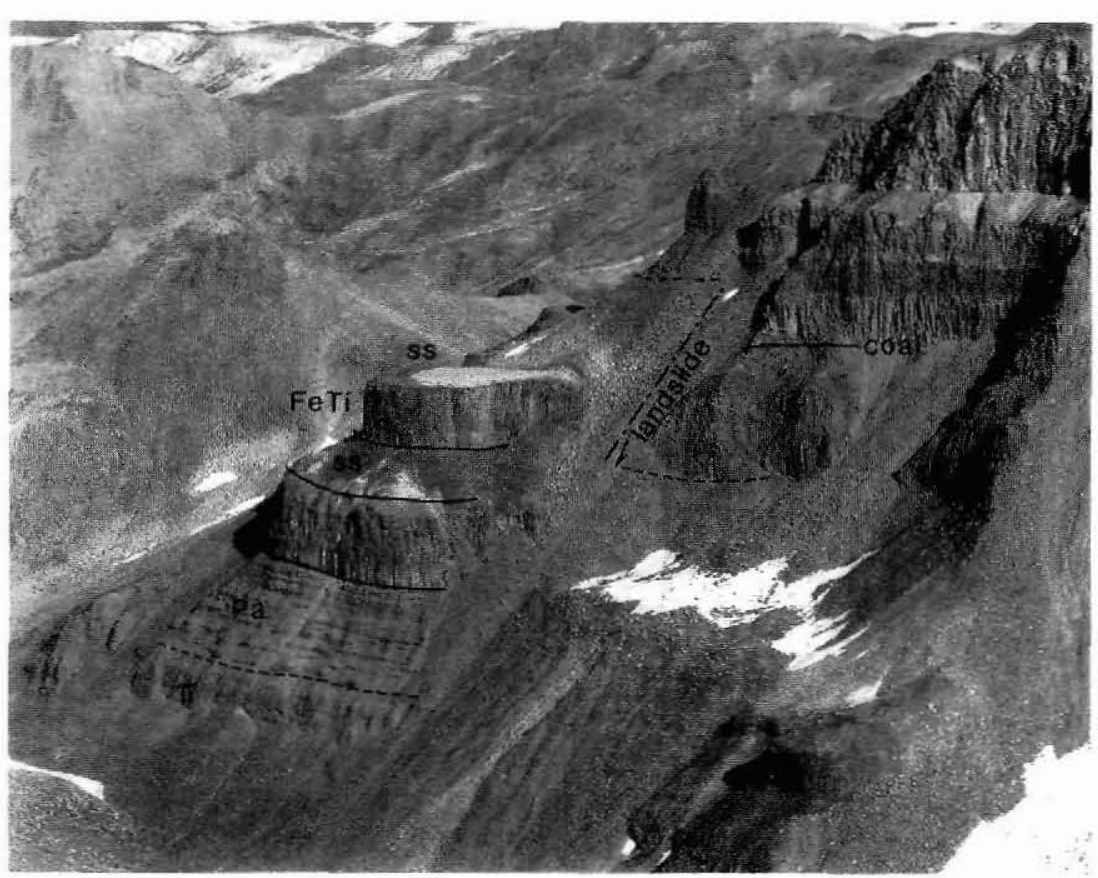


suaq and runs into sediments in south-eastern Nûgssuaq (fig. 5). This indicates a shield-formed top surface of the southern and eastern part of the Vaigat Formation, as earlier suggested for Nûgssuaq by Münther (1973). The top surface sloped towards the south and east; no erosion has been seen on it, and the possibility remains open that picrites of the Vaigat Formation continued to erupt in the north while feldspar-phyric basalts of the Maligât Formation erupted in the south.

When the feldspar-phyric basalts of the Maligât Formation (Rinks Dal Member) started erupting on Disko the topography on Disko and Nûgssuaq was quite uneven. To the north the picrites of the Vaigat Formation formed a broad, shield-like high which in some areas terminated in hyaloclastite fans. The Disko gneiss ridge was exposed over an at least $50 \mathrm{~km}$ long stretch in central and southern Disko and formed the western shore of a large water-filled basin in which black mudstones slowly accumulated. The eastern shore faced a low-lying fluvial plain where sandstones were deposited. The position of the eastern shoreline went through several oscillations with time, so that the Tertiary nonmarine sediments form alternating sequences of shale and sandstone. These sequences were described from south-eastern Nûgssuaq by Koch (1959) and from eastern Disko around peak $845 \mathrm{~m}$ by Pedersen $(1987,1989)$; however, firm correlations between the sediments on Disko and Nûgssuaq, and between sediments and volcanics, have not been established.

The oldest volcanic rocks in southern and central Disko belong to the lower part of the Rinks Dal Member and spread out in the water-filled basin mainly as subaqueous lava flows (Heinesen, 1987). Chemically, they all belong to the very common Ti-poor group (figs 1 and 2), and they do not form good marker horizons.

The pahoehoe unit followed these older lavas, and the characteristic pillow breccias probably formed because of relatively low flow rates of magma into the water. Thanks to the pillow breccia horizon a snapshot of the extension and depth of the water-filled basin can be constructed as shown in fig. 4 . At that time the basin was around $60 \mathrm{~m}$ deep and extended over at least 1600 $\mathrm{km}^{2}$ on Disko. The pahoehoe unit constitutes a considerable eastward progradation of the volcanic pile, and in an area of $900 \mathrm{~km}^{2}$ in eastern Disko it is the first volcanic rocks deposited except for some tuff horizons. The breccias of the pahoehoe unit displaced around 100 $\mathrm{km}^{3}$ of water and substantially reduced or even annihilated the water basin on Disko.

The FeTi unit followed the pahoehoe unit with one or a few flows between. When the FeTi unit started forming the high parts of the picrite shield of the Vaigat Formation were still exposed on Nûgssuaq while on
Disko the picrites were completely buried in the lower lavas of the Rinks Dal Member. The Disko gneiss ridge was likewise covered except for small remnants of the southernmost part. The pahoehoe unit and coeval sediments had filled the basin east of the ridge, and thus the topography on Disko was for the first time relatively level, with no physical barrier between east and west. This enabled the FeTi unit to spread over a large area from the eruption sites in western Disko; a conservative estimate indicates that the unit has covered at least $12000 \mathrm{~km}^{2}$ in Disko and Nûgssuaq with around 1500 $\mathrm{km}^{3}$ of lava. This contributes to its potential as a marker horizon. However, the many laterite layers between the subaerial flows indicate a low eruption rate, so that the FeTi unit is a less precise time-marker than the pahoehoe unit except when individual flows are considered.

The eruption of the first lavas of the FeTi unit seems to have followed a comparatively long period of volcanic quiescence. In this period the lavas in eastern Disko were again covered by sand and silt (fig. 1), while a prominent lateritic soil horizon accumulated on the lavas in the west. This stage marks the maximum westerly extent of clastic non-volcanic sediments during the formation of the Rinks Dal Member.

With the renewed volcanic activity the FeTi lavas covered the rest of the Disko gneiss ridge. They flowed east on the sediment-covered plain to terminate as buried invasive lavas in the simultaneously accumulating sediments, and eventually they covered larger areas than any of the earlier volcanic units (fig. 5). On Nûgssuaq they lapped onto the picrite shield in the west and entered the Aussivik Member mudstones in the east.

The sediments interspersed with the lavas of the FeTi unit must be very nearly time-equivalent, and this provides a unique opportunity of sediment correlation across different facies. It can thus be concluded that the Aussivik Member shales are time-equivalent to sandstones and shales around $700 \mathrm{~m}$ a.s.l. in northern east Disko, and to fluvial sandstones in the other parts of Disko (fig. 1). The Aussivik Member shales possibly formed in the last remains of the once extensive lake between the gneiss ridge, the volcanics and the fluvial plain.

Finally, the distribution of the FeTi unit shows that there was at that time a modest easterly dipping topographical gradient, unaffected by the buried gneiss ridge. A similar easterly gradient has been shown to be present when the later Nordfjord Member was deposited (Larsen \& Pedersen, 1989). This is evidence that the continental margin, which later collapsed west of the gneiss ridge, had not yet begun to sag or, if it had, the sagging was counteracted by increased production of volcanics west of the ridge. 


\section{References}

Byerly, G. \& Swanson, D. 1978: Invasive Columbia River Basalt flows along the northwestern margin of the Columbia Plateau, North-Central Washington. Abstr. geol. Soc. Amer. 10(3), 98 only.

Duffield, W. A., Bacon, C. R. \& Delaney, P. T. 1986: Deformation of poorly consolidated sediment during shallow emplacement of a basalt sill, Coso Range, California. Bull. Volcanol. 48, 97-107.

Hald, N. 1976: Early Tertiary flood basalts from Hareøen and western Nûgssuaq, West Greenland. Bull. Grønlands geol. Unders. 120, $36 \mathrm{pp}$.

Hald, N. \& Pedersen, A. K. 1975: Lithostratigraphy of the early Tertiary volcanic rocks of central West Greenland. Rapp. Gronlands geol. Unders. 69, 17-24.

Heinesen, M. 1987: Nedre tertiære basaltbreccier og undervands-lavastrømme, sydlige Disko, Vestgrønland: Strukturelle, petrografiske og mineralogiske studier. Cand.scient. thesis. Københavns Universitet. 4 vols, 118 pp. text.

Koch, B. E. 1959: Contribution to the stratigraphy of the non-marine Tertiary deposits on the south coast of the Nûgssuaq peninsula, northwest Greenland. Bull. Grønlands geol. Unders. 22 (also Meddr Grønland 162,1), 100 pp.

Koch, B. E. \& Pedersen, K. R. 1960: Geological map of Atanikerdluk and environs, 1:10 000. Bull. Grønlands geol. Unders. 23 (also Meddr Grønland 162,4), 38 pp.
Larsen, L. M. \& Pedersen, A. K. 1989: New geological investigations in eastern Disko: redeposited volcanoclastic sediments with rhyolite from the Nordfjord Member. Rapp. Grønlands geol. Unders. 145, 45-49.

Münther, V. 1973: Results from a geological reconnaissance around Svartenhuk Halvø, West Greenland. Rapp. Grønlands geol. Unders. 50, $26 \mathrm{pp}$.

Pedersen, A. K. 1975a: New mapping in north-western Disko 1972. Rapp. Grønlands geol. unders. 69, 25-32.

Pedersen, A. K. 1975b: A pillowed sill from the Atanikerdluk area, Nûgssuaq. Rapp. Grønlands geol. Unders. 69, 17-24.

Pedersen, A. K. 1985: Lithostratigraphy of the Tertiary Vaigat Formation on Disko, central West Greenland. Rapp. Grønlands geol. Unders. 124, $30 \mathrm{pp}$.

Pedersen, A. K. \& Ulff-Møller, F. 1987: Geological map of Greenland, 1:100 000 Mellemfjord 69 V.1 Nord. Copenhagen: Geol. Surv. Greenland.

Pedersen, G. K. 1987: New sedimentological data on Lower Tertiary shales from Disko and Nûgssuaq, West Greenland. Rapp. Grønlands geol. Unders. 135, 17-25.

Pedersen, G. K. 1989: A fluvial-dominated lacustrine delta in a volcanic province, W Greenland. In Whateley, M. K. G. \& Pickering, K. T. (edit.) Deltas: sites and traps for fossil fuel. Spec. Publ. geol. Soc. Lond. 41, 139-146.

Schmincke, H.-U. 1967: Fused tuff and peperites in southcentral Washington. Bull. geol. Soc. Amer. 78, 319-330. 